\title{
RELATIVE CHANGES OF CHEMICAL PROPERTIES OF CALCAREOUS SOILS TREATED BY ORGANIC ACIDS UNDER DIFFERENT SALINITY LEVELS OF IRRIGATION WATER \\ Tantawy, Manal F. ${ }^{1}$; E. A. Abou Hussien ${ }^{2}$; M. A. Ahmed ${ }^{2}$ and
} A. A. $\mathbf{A l i}^{2}$

${ }^{1}$ Soils, Water and Environment Inst. Res. Agric. Res. Center, Giza-Egypt. ${ }^{2}$ Soil Sci. Dept. Fac. of Agric. Minoufiya Univ. Egypt

\begin{abstract}
This laboratory experiment was carried out to study the individual and combined effect of two organic acids (humic and oxalic acids) and salinity levels of irrigation water on the changes of chemical properties and the content of available phosphorus of two calcareous soils of Egypt. The soils were treated by either humic or oxalic acid at application rates of $0,0.1,0,2$ and $0.4 \%$ and irrigated by one of irrigation water resources varied in their salinity levels at $100 \%$ of soil field capacity. The used three water resources were tap water (W1), sea water (W3) and mixed water between W1 and W3 with mixed ratio of 1:1 (W2). This experiment was carried out in plastic pots, where it arranged in completely block randomized system with three replicates. These pots were incubated at room temperature $\left(25 \pm 2{ }^{\circ} \mathrm{C}\right)$ for 6 months. After that, soil $\mathrm{pH}, \mathrm{EC}\left(\mathrm{dSm}^{-1}\right), \mathrm{CEC}(\mathrm{meq} / 100 \mathrm{~g})$, total and active $\mathrm{CaCO}_{3}(\%)$ and the content of available $P(\mathrm{mg} / \mathrm{kg})$ were determined.

Organic acids applications resulted in a decrease of soil $\mathrm{pH}$ and its content of total $\mathrm{CaCO}_{3} \%$ and increased soil EC $\left(\mathrm{dSm}^{-1}\right)$, CEC (meq/100g), and the content of active $\mathrm{CaCO}_{3}(\%)$ and available $\mathrm{P}(\mathrm{mg} / \mathrm{kg})$. On the other hand, increasing salinity levels of irrigation water resulted in a decrease of soil content of total $\mathrm{CaCO}_{3}$ and increased soil $\mathrm{pH}, \mathrm{EC}, \mathrm{CEC}$, active $\mathrm{CaCO}_{3}$ and available $\mathrm{P}$. The relative changes (RC, $\%$ ) of the studied soil properties were varied widely from soil to anther depending on type and application rate of the used organic acids and salinity level of irrigation water. Keywords: Calcareous soils, Organic acids, Salinity level, Relative changes, Soil chemical properties and Available phosphorus.
\end{abstract}

\section{INTRODUCTION}

In Egypt the newly reclaimed soils at El-Nubariya and Borg El-Arab regions cover more than 900.000 feddans (feddan $=4200 \mathrm{~m}^{2}$ ) of which 290.000 feddans are calcareous soils (Moursy, 2002). Studies on the physical, chemical and mineralogical characteristics of some calcareous soils of Egypt to be classified and evaluated for agriculture purposes were carried by Abd El-Kader (2006), who showed that, the content of $\mathrm{CaCO}_{3}$ in the soils of El-Nobariya area in the Western Desert is very high and varies widely from 23.04 to $53.18 \%$.

Agriculture in Egypt depends mainly on irrigation from the River Nile $\left(55.5 \times 10^{9} \mathrm{~m}^{3} /\right.$ year). The need to provide additional land to increase food production compels the farmers to use all sources of water. Therefore, the use of low quality water, such as ground water, drainage water, treated waste water and even diluted sea water, should be considered as complementary 
Tantawy, Manal F. et al.

sources, for the expansion of irrigated agriculture and agricultural development. The high salinity of irrigation water decreases crop yield, or even causes failure of crop establishment, due to specific ion effect, or total salt buildup in the root zone, or inadequate maintenance of soil physical properties. In this respect, several factors have been evaluated, as they limit suitability of water for irrigation purposes. These factors are chemical composition of water, which affect greatly on the physical and chemical properties of soils, crop species, and types of soil and water irrigation management. Many investigators also showed that soil amendments greatly affected the physical and chemical properties of the soils and they could reduce the harmful effect of saline irrigation water (Fayed, 2009 and Abou Hussien et al., 2009 and 2010).

El-Maghraby and Shaban (2011) found that, a slight decrease of soil $\mathrm{pH}$ values after wheat harvesting in the soil treated by organic fertilizers compared to untreated soil. This may be due to the soil buffering capacity. On the other hand, the favorable effects of organic fertilizers on decreasing soil $\mathrm{pH}$ due to organic and inorganic acids formed during organic fertilizer decomposition as well as improving the structure of the calcareous soils was also reported by Beheiry and Soliman (2005) and El-Fishy (2009). Ismail et al. (1996) reported that EC values increased in calcareous soil treated with organic fertilizer. Many anothers also showed an increase in EC which accompanied by compost and manure application (Abou Hussien et al, 2012; Emam, 2011 and Gohar, 2011).

This work was carried out to study the changes in some chemical properties of calcareous soils as affected by source and application rate of two organic acids and salinity levels of irrigation water individually or in combination. The studied soil properties were the content (\%) of both total and active calcium carbonate, cation exchange capacity, electrical conductivity, $\mathrm{pH}$ and the content of available phosphorus.

\section{MATERIALS AND METHODS}

\section{Soil Sampling}

This work was carried out in Soil Science Department, Faculty of Agriculture, Minoufiya University, Shibin El-Kom to study some chemical properties of two calcareous soils and its affected by individual and combined treatments of both organic acids (source and application rate) and salinity level of irrigation water. For achieve this purpose, two surface $(0-20 \mathrm{~cm})$ soil samples were collected from two calcareous soils varied in their contents (\%) of total calcium carbonate $\left(\mathrm{CaCO}_{3}\right)$. The first soil was taken from Hawary Farm, El-Nobariya, Behara Governorate (soil 1) and the second was taken from Bohos Farm, Borg El-Arab, Alexandria Governorate (soil 2). The collected soil samples of each location were air dried, good mixed and ground to pass through a $2 \mathrm{~mm}$ (10 meshes) sieve. Fine soils $(<2 \mathrm{~mm})$ were kept and analyzed for some physical and chemical properties according to the methods described by Cottenie et al. (1982); Page et al. (1982) and Kim (1996). The obtained data were recorded in Table (1). 
Table (1): Some physical and chemical properties of the studied calcareous soils.

\begin{tabular}{|c|c|c|}
\hline \multirow{2}{*}{$\begin{array}{c}\text { Soil properties } \\
\text { and units }\end{array}$} & \multicolumn{2}{|c|}{ Soil sample number } \\
\hline & Soil 1 & Soil 2 \\
\hline \multicolumn{3}{|c|}{ Particle size distribution (\%) } \\
\hline Coarse sand & 51.8 & 22.5 \\
\hline Fine sand & 12.7 & 42.4 \\
\hline Silt & 33.0 & 20.5 \\
\hline Clay & 2.5 & 14.6 \\
\hline Texture class & Sandyloam & Sandyloam \\
\hline Field capacity \% & 20.5 & 26.5 \\
\hline Total $\mathrm{CaCO}_{3} \%$ & 29.20 & 41.80 \\
\hline Active $\mathrm{CaCO}_{3} \%$ & 9.60 & 10.80 \\
\hline O.M. \% & 0.62 & 0.22 \\
\hline CEC, meq/100g soil & 17.39 & 16.50 \\
\hline $\mathrm{pH}(1: 2.5)$ soil:water susp. & 7.77 & 7.92 \\
\hline EC. in extract $(1: 5), \mathrm{dSm}^{-1}$ & 4.12 & 0.92 \\
\hline \multicolumn{3}{|c|}{ Soluble ions ( meq/l ) } \\
\hline $\mathrm{Ca}^{2+}$ & 9.90 & 1.88 \\
\hline $\mathrm{Mg}^{2+}$ & 4.80 & 1.38 \\
\hline $\mathrm{Na}^{+}$ & 25.4 & 5.62 \\
\hline $\mathrm{K}^{+}$ & 1.61 & 0.36 \\
\hline $\mathrm{CO}_{3}{ }^{2-}$ & 0.00 & 0.00 \\
\hline $\mathrm{HCO}_{3}{ }^{-}$ & 1.98 & 2.97 \\
\hline $\mathrm{Cl}^{-}$ & 18.00 & 3.50 \\
\hline $\mathrm{SO}_{4}{ }^{2-}$ & 21.73 & 2.77 \\
\hline Available phosphorus (mg/kg) & 9.2 & 7.8 \\
\hline
\end{tabular}

\section{Irrigation Water}

Three irrigation water resources varied in their salinity levels were used in this study. These resources were tap water (W1), mixed water of tap water and sea water at mixing ratio of 1:1 (W2) and sea water (W3). The used sea water in this study was brought from Mediterranean Sea water at Northern Coast of the El-Hamam City, Mersa Matruh Governorate at $63 \mathrm{~km}$ from Alexandria in July, 2010. The chemical compositions of these three water resources were carried out according to methods described by A.O.A.C. (2000) and the obtained data were recorded in Table (2).

Table (2): The chemical composition of the used three irrigation water resources

\begin{tabular}{|c|c|c|c|c|c|c|c|c|c|c|c|}
\hline \multirow{3}{*}{ water } & \multirow{3}{*}{ pH } & \multirow{3}{*}{$\begin{array}{c}\mathrm{EC} \\
\mathrm{dSm}^{-1}\end{array}$} & \multicolumn{8}{|c|}{ Soluble ions (meq/l) } & \multirow{3}{*}{ SAR } \\
\hline & & & \multicolumn{4}{|c|}{ Cations } & \multicolumn{4}{|c|}{ Anions } & \\
\hline & & & $\mathrm{Ca}^{2+}$ & $\mathrm{Mg}^{2+}$ & $\mathrm{K}^{+}$ & $\mathrm{Na}^{+}$ & $\mathrm{Cl}^{-}$ & $\mathrm{CO}_{3}{ }^{2-}$ & $\mathrm{HCO}_{3}{ }^{-}$ & $\mathrm{SO}_{4}{ }^{2-}$ & \\
\hline W1 & 7.70 & & 3.1 & 1.8 & 0.15 & 8.2 & 3.5 & 0.0 & 9.4 & 0.35 & 5.2 \\
\hline W2 & 7.76 & 30.87 & 12.0 & 65.5 & 5.6 & 290.4 & 288 & 0.0 & 6.4 & 86.3 & 46.6 \\
\hline W3 & 8.02 & 67.30 & 14.0 & 133.0 & 10.7 & 635.3 & 625 & 0.0 & 2.5 & 165.6 & 74.1 \\
\hline
\end{tabular}

\section{Organic Acids}

Two organic acids used in this study were humic and oxalic acids $\left.(\mathrm{COOH})_{2} \cdot 2 \mathrm{H}_{2} \mathrm{O}\right)$. The used humic acid was isolated and purified from potassium humate for Humintech ${ }^{\circledR}$ Company in Spain according to the methods described by Kononova (1966) and Schnitzer and Khan (1978), 
Tantawy, Manal F. et al.

respectively. The chemical composition of humic acid was recorded in Table (3).

Table (3): The chemical composition of the used humic acid

\begin{tabular}{|l|c|l|c|}
\hline \multicolumn{4}{|c|}{ Properties and composition } \\
\hline $\begin{array}{c}\text { Functional groups } \\
\text { (mmolc/g) }\end{array}$ & Value & $\begin{array}{c}\text { Elemental composition } \\
(\%)\end{array}$ & Value \\
\hline Total acidity & 7.50 & Carbon ( C) & 51.30 \\
\hline $\mathrm{COOH}$ groups & 4.27 & Hydrogen (H) & 4.30 \\
\hline Total-OH groups & 3.78 & Nitrogen (N) & 2.70 \\
\hline Phenolic-OH groups & 3.26 & Oxygen (O) & 41.55 \\
\hline Alcoholic-OH groups & 0.52 & Phosphorus (P) & 0.15 \\
\hline \multicolumn{2}{|l|}{} & C/N ratio & 19.00 \\
\hline
\end{tabular}

\section{The Experiment}

Plastic pots (144 pots) with $10 \mathrm{~cm}$ inter diameter and $7 \mathrm{~cm}$ depth were used. These pots were divided into two main groups represented the main factor (A) or the used two calcareous soils (72 pot for each group). A $400 \mathrm{gm}$ of soil 1 and soil 2 were placed in each pot of main groups. The pots of each main group were divided into two groups (36 pot/ group), representing factor $(\mathrm{B})$ or the treatments of the used organic acids i.e. humic and oxalic acids. The pots of each organic acid group were divided into four groups (9 pots/ group) where represent the application rate of the used organic acids. These rates were $0.0,0.1,0.2$ and $0.4 \%$, which equivalent to $0.0,0.4,0.8$ and $1.6 \mathrm{gm}$ organic acids pot ${ }^{-1}$. These applications were good mixed with soil. After that, the pots of each organic acid rate group were divided into three groups (3 pots for each group) which represent the treatments of the used three irrigation water resources (W1, W2 and W3). All pots were irrigated at $100 \%$ of soil field capacity (FC) of each soil. The experimental pots were arranged in completely randomized block design with three replicates. These pots were incubated at room temperature $\left(25 \pm 2{ }^{\circ} \mathrm{C}\right)$ for 6 months. During the incubation period, irrigation water resources were added based on the weight every three days to kept the moisture content at the tested moisture content. At the end of incubation period, the soil of each pot was taken, mixed, air dried and ground to pass through a $2 \mathrm{~mm}$ sieve. Fine soils $(<2 \mathrm{~mm})$ were kept and analyzed for some chemical properties and its content of available phosphorus according to the methods described by Cottenie et al. (1982); Page et al. (1982) and Kim (1996).

\section{RESULTS AND DISCUSSION}

\section{Soil pH}

The presented data in Table (4) showed that, the soil $\mathrm{pH}$ of calcareous soils was slightly decreased with the increase of applied organic acids. These decreases in $\mathrm{pH}$ were attributed to the carbonic acid produced from reaction of organic acids with calcium carbonate and other compounds in soil. At the same application rate of organic acids, the obtained decreases in soil $\mathrm{pH}$ associated the treatments of humic acid were higher than those resulted from oxalic acid treatments. This trend was obserived in the two 
calcareous soils. Similar results were obtained in the calcareous soils treated with compost by Panahpour et al. (2011) and Abou Hussien et al. (2012).

The presented data in Table (4) showed that, soil pH was slightly increased with increasing salinity level of irrigation water. So the high increase of soil pH was found in the soil irrigated by sea water (W3). The found increases in soil $\mathrm{pH}$ as a result of salinity level increases attributed to the cations presented in irrigation water as $\mathrm{Ca}^{++}, \mathrm{Mg}^{++}$and $\mathrm{Na}^{+}$replaced $\mathrm{H}^{+}$on surfaces exchangeable sites of clay and organic matter. With different treatments under study, the effect of resulting SAR values of these water resources on calcareous soil $\mathrm{pH}$ was positive which due to displacement of $\mathrm{Na}^{+}$by hydrolysis liberating hydroxide ion which remains in solution (AlBusaidi and Cookson 2003). This explained by the following equation.

$\left(\right.$ Ca-Soil-Na) $+2 \mathrm{H}_{2} \mathrm{O} \leftrightarrow($ Ca-Soil- $\mathrm{H})+\mathrm{Na}^{+}+\mathrm{OH}^{-}$

Table (4): Effect of the studied treatments on the calcareous soils $\mathrm{pH}$

\begin{tabular}{|c|c|c|c|c|c|c|c|c|c|c|}
\hline \multirow{2}{*}{$\begin{array}{l}\text { Soil } \\
\text { No. }\end{array}$} & \multirow{2}{*}{$\begin{array}{l}\text { Water } \\
\text { resource } \\
\text { (B) }\end{array}$} & \multirow{2}{*}{ Control } & \multicolumn{4}{|c|}{ Humic acid \% (A) } & \multicolumn{4}{|c|}{ Oxalic acid \% (A) } \\
\hline & & & 0.10 & 0.20 & 0.40 & Mean & 0.10 & 0.20 & 0.40 & Mean \\
\hline \multirow{4}{*}{1} & W1 & 8.17 & 8.15 & 8.10 & 8.09 & 8.13 & 8.16 & 8.16 & 8.14 & 8.16 \\
\hline & W2 & 8.25 & 8.15 & 8.13 & 8.10 & 8.16 & 8.23 & 8.22 & 8.21 & 8.23 \\
\hline & W3 & 8.25 & 8.25 & 8.23 & 8.20 & 8.23 & 8.25 & 8.24 & 8.21 & 8.24 \\
\hline & Mean & 8.22 & 8.18 & 8.15 & 8.13 & 8.17 & 8.21 & 8.21 & 8.19 & 8.21 \\
\hline \multicolumn{3}{|c|}{ L.S.D at 0.05} & \multicolumn{4}{|c|}{$\mathrm{B}=0.041$} & $A=0.025$ & $\mathrm{~B}=0.022$ & & \\
\hline \multirow{4}{*}{2} & W1 & 8.17 & 8.18 & 8.17 & 8.15 & 8.17 & 8.18 & 8.18 & 8.16 & 8.17 \\
\hline & W2 & 8.30 & 8.17 & 8.15 & 8.11 & 8.18 & 8.19 & 8.18 & 8.20 & 8.22 \\
\hline & W3 & 8.35 & 8.31 & 8.29 & 8.27 & 8.31 & 8.33 & 8.31 & 8.29 & 8.32 \\
\hline & Mean & 8.27 & 8.22 & 8.20 & 8.18 & 8.22 & 8.23 & 8.22 & 8.22 & 8.24 \\
\hline \multicolumn{3}{|c|}{ L.S.D at 0.05} & \multicolumn{3}{|c|}{$A=0.037 \quad B=0.032$} & & $A=0.071$ & $\mathrm{~B}=0.062$ & & \\
\hline
\end{tabular}

\section{Total soluble salts (EC)}

The presented data in Table (5) showed that, calcareous soils EC $\left(\mathrm{dSm}^{-1}\right)$ was slightly increased as a result of organic acids application at different rates. The effects of humic acid and oxalic acid on increasing soil EC in the two calcareous soils were nearly similar. These increases were resulted from the dissolved and solubilizing effects of added organic acids on some soil compounds. Recently Abou Hussien et al. (2012); Emam (2011) and Gohar (2011) concluded that, under clayey, sandy and calcareous soils conditions of Egypt, different applications of many organic manures sources resulted in an increase of soil EC. These increases are depended on soil properties, source and chemical composition and application rates of the used organic manures. This is in harmony with the findings of Boroojeni et al. (2007).

The presented data in Table (5) show the calculated values of relative change $(\mathrm{RC}, \%)$ of soil EC compared with its original values in the tested soils using the following equation. 
Tantawy, Manal F. et al.

$$
R C(\%)=\frac{(E C \text { in the treated soil }- \text { Original soil EC })}{\text { Original soil EC }} \times 100
$$

The recorded values of RC EC show that, these values were positive under different treatments of organic acids. The RC of EC values found in the soil 2 were higher than those found in the soil 1 . This trend is due to results from the differences among these soil properties and its effect on the behavior of added acids in the soil. Also, in the two soils, the RC of EC values obtained from HA and OA treatments were high. This trend was attributed to the behavior of these acids and its reactions with different soil compounds. The presented data in Table (5) showed that, the calcareous soils content of total soluble salts (EC) which measured as $\mathrm{dSm}^{-1}$ and its $\mathrm{RC}(\%)$ was increased with increasing salinity level of irrigation water. So the high values of $E C$ and its $R C$ values were recorded in the soils irrigated by W3. This trend was found in the two soils with different treatments of organic acids. The obtained increases were generally resulted from the soluble salts accumulated in the soil during the experimental period. The high values of $\mathrm{RC}$ were found in the soil treated with W3 and application rate of $0.4 \%$ of the evaluated organic acids. Similar findings were reported by Mohamed et al. (2007); Ragab et al. (2008); Hamad (2009) and Mojiri et al. (2011).

At different salinity levels of the used irrigation water resources with all organic acids treatments, the effect of SAR values or sodium concentration of these water resources on calcareous soil EC was positive. This positive effect of SAR of irrigation water on soil EC due to sodium in irrigation water is gradually replaced by calcium in calcium carbonate with the formation for soluble salts as $\mathrm{Na}_{2} \mathrm{CO}_{3}$ and $\mathrm{NaHCO}_{3}$, which it responsible on raising the soil EC. Similar results were reported by Al-Busaidi and Cookson (2003).

\section{Cation exchangeable capacity (CEC)}

The presented data in Table (6) showed that, the CEC were increased significantly with increasing organic acids applied in the two soils under study. At same application rate of organic acids in the two calcareous soils, the obtained increases in soil CEC associated the treatments of HA were higher than that recorded with the treatments of OA. The obtained increase in CEC with organic acids applications was resulted from the greater CEC values of the used organic acids which resulted in an increase of surface negative charges of calcareous soils. Similar results were obtained in the calcareous soils treated with humic acid by Caravaca et. al. (1999). The recorded values of RC (\%) of soil CEC in Table (6) show a wide variation in the effects of the studied factors on CEC of calcareous soils. These values show that, all values of RC of CEC were positive and it become more positive with increasing rate of added organic acid. The values of RC of CEC in the soil treated with HA were more positive compared with those results from the treatments of $O A$. 
J. Soil Sci. and Agric. Eng., Mansoura Univ., Vol. 3 (10), October, 2012 5-6 
Tantawy, Manal F. et al.

This trend was found at different application rates in the two calcareous soils. These findings may be attributed to the high stable state of HA compared with that of $\mathrm{OA}$ characterized by high solubility. So the decomposition rate of $\mathrm{HA}$ was lower than that of $\mathrm{OA}$. With different application rates of both $\mathrm{HA}$ and $\mathrm{OA}$, the values of $\mathrm{RC}$ of $\mathrm{CEC}$ in soil 1 were higher than those found in soil 2. In this respect Hassan (2009) reported similar relationships between soil CEC and many organic manures sources under different soil conditions.

The presented data in Table (6) showed that, the cation exchange capacity (CEC) of calcareous soils and its relative change (RC \%) were increased with increasing salinity level of irrigation water. So, the high CEC values were recorded with the treatments of $\mathrm{W} 3$ and the lowest values were recorded with $\mathrm{W} 1$ treatments. These increases of CEC were recorded in the two calcareous soils. These increases associated the salinity level increased with both treatments of $\mathrm{HA}$ and OA. Similar conclusions were reported by Prieto-Mendez et al. (2011). Irrigation water contains excess soluble sodium $\left(\mathrm{Na}^{+}\right)$ions which resulted in a separation soil particles followed by increase of specific surface area and surface negative charges. Also, irrigation water causes salt accumulation in soil and quickly break down soil structure which noticed in calcareous soil (Levy et. al., 2003). In this respect FAO (2002); Ragab et al. (2008) and Leal et.al. (2009) obtained similar results with some calcareous soils.

Total calcium carbonate $\left(\mathrm{T}-\mathrm{CaCO}_{3}\right)$

Data in Table (7) showed that, the calcareous soils content (\%) of total calcium carbonate $\left(\mathrm{T}-\mathrm{CaCO}_{3}\right)$ was decreased significantly with increasing the application rates of the used organic acids. This decrease in the $\mathrm{T}-\mathrm{CaCO}_{3}$ content in the calcareous soils is due to dissolving effect of added organic acids on soil $\mathrm{CaCO}_{3}$. This trend was in agreement with the results obtained by Moreno et al. (2006). Also these organic acids reacted with calcium carbonate $\left(\mathrm{CaCO}_{3}\right)$ causing decrease of calcium carbonate in soil and convert it to calcium humate or calcium oxalate plus carbonic acid. Similar conclusions were reported by Mohamed et al. (2007). They explained the previous reaction by the two following equations:

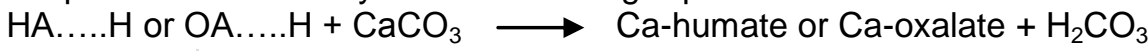
$\mathrm{H}_{2} \mathrm{CO}_{3} \longrightarrow \mathrm{H}_{2} \mathrm{O}+\mathrm{CO}_{2}$

Also, the data presented in Table (7) show, with soil 1 the obtained decreases in the soil content of $\mathrm{T}-\mathrm{CaCO}_{3}$ resulted from the treatments of $\mathrm{OA}$ and $\mathrm{HA}$, but in soil 2 humic acid have a slightly decrease effect on the content of $\mathrm{T}-\mathrm{CaCO}_{3}$. The presented data in Table (7) show the calculated values of relative change (RC, \%) of soil content of $\mathrm{T}-\mathrm{CaCO}_{3}$ compared with its original values in the tested soils. The values of $\mathrm{RC}$ of $\mathrm{T}_{-}-\mathrm{CaCO}_{3}$ associated the treatments of $\mathrm{HA}$ and $\mathrm{OA}$ were negative in the two calcareous soils, where the values increased negatively with the increase of added organic acids. At the same application rate of the two acids, the values of $\mathrm{RC}(\%)$ in the soil 1 were more negative than these found in the soil 2. This may be attributed to the low original soil 1 content of $\mathrm{T}-\mathrm{CaCO}_{3}$ than that in soil 2. Also, for $\mathrm{RC}$ values, it may be noticed that, the decrease of organic acids in the calcareous soil content of $\mathrm{T}-\mathrm{CaCO}_{3}$ varied from acid to another depending on 
its chemical composition. In this respect Sarwar et al. (2008) found similar results.

The presented data in Table (7) showed that, the calcareous soils content (\%) of total calcium carbonate was decreased with increasing salinity level of irrigation water. These decreases were resulted from some reactions and dissolving effects of added soluble salts with the native $\mathrm{CaCO}_{3}$ in the soil. In this respect, Abou Hussien et al., (2012) and Hamad (2009) obtained similar result. Also, the decrease in the content of $\mathrm{T}-\mathrm{CaCO}_{3}$ could be explain by the increase of sodium $\left(\mathrm{Na}^{+}\right)$ions concentration in irrigation water than the concentrations of $\mathrm{Ca}^{2+}$ and $\mathrm{Mg}^{2+}$ ions ( high SAR values), where $\mathrm{Na}^{+}$ions adsorbed on calcium carbonate surfaces and formed soluble sodium carbonate $\left(\mathrm{Na}_{2} \mathrm{CO}_{3}\right)$ and consumed a part of $\mathrm{T}-\mathrm{CaCO}_{3}$ according to following equation:

$2 \mathrm{NaCl}+\mathrm{CaCO}_{3} \longrightarrow \mathrm{Na}_{2} \mathrm{CO}_{3}+\mathrm{Ca}(\mathrm{Cl})_{2}$

So, all $\mathrm{RC}(\%)$ values of $\mathrm{T}-\mathrm{CaCO}_{3}$ in the two calcareous soils as affected by salinity levels of irrigation water were negative and its become more negative at high salinity level (W3. Also, these values were varied from soil to another depending on these soils properties especially the content (\%) of $\mathrm{T}-\mathrm{CaCO}_{3}$. Similar conclusions were reported by Al-Busaidi and Cookson (2003)

Active calcium carbonate $\left(\mathrm{A}-\mathrm{CaCO}_{3}\right)$

The presented data in Table (8) showed that, the calcareous soils content (\%) of active calcium carbonate $\left(\mathrm{A}-\mathrm{CaCO}_{3}\right)$ was increased with increasing organic acids applied to the two soils under study. At the same application rate of organic acids, the obtained increase in the soil content of $\mathrm{A}-\mathrm{CaCO}_{3}$ associated the treatments of $\mathrm{HA}$ was higher than that resulted from the treatments of $\mathrm{OA}$. The increase in the soil content of $\mathrm{A}-\mathrm{CaCO}_{3}$ associated the treatments of organic acids could be resulted from the reaction between organic acids with total $\mathrm{CaCO}_{3}$ in soils and converted part of total $\mathrm{CaCO}_{3}$ to A-CaCO${ }_{3}$. In this respect DelCampillo et al. (1992) and Reyhanitabar and Gilkes (2010) found similar results.

Data in Table (8) showed that the values of $R C(\%)$ of soil content of A$\mathrm{CaCO}_{3}$ were positively affected by the different treatments of organic acids. It increased with increasing rate of added organic acid. At the same application rate of $\mathrm{HA}$ the values of $\mathrm{RC}$ of $\mathrm{A}-\mathrm{CaCO}_{3}$ were higher than that with $\mathrm{OA}$. This trend was found in the two soils.

The presented data in Table (8) showed that, the calcareous soils content (\%) of active calcium carbonate $\left(\mathrm{A}-\mathrm{CaCO}_{3}\right)$ was little decreased with increasing salinity levels of irrigation water, where the high decrease was found in the soils irrigated with sea water (W3). This decrease in the content $(\%)$ of $\mathrm{A}-\mathrm{CaCO}_{3}$ was found with the two calcareous soils under study. So, RC $\%$ of $\mathrm{A}-\mathrm{CaCO}_{3}$ was increased negatively with increasing salinity level of irrigation water. 
Tantawy, Manal F. et al.

7-8

1026 
Available phosphorus

The presented data in Tables (9) showed that, the contents $\left(\mathrm{mg} \mathrm{kg}^{-1}\right)$ of available phosphorus in calcareous soil were greater affected by the studied treatments, where it increased with the increase in the application rates of organic acids in both soils. These increases of available phosphorus contents in soil 2 were greater than those in soil 1. The obtained increases in calcareous soils content of available $\mathrm{P}$ as a result of the treatments with organic acids were resulted from the decrease of soil $\mathrm{pH}$ associated the treatments of organic acids which resulted in a more release of soil P (Tan, 2003), bicarbonate ions $\left(\mathrm{HCO}_{3}\right)$ resulted from organic acids decomposition are reacted with soluble $\mathrm{Ca}^{2+}$ formed $\mathrm{Ca}\left(\mathrm{HCO}_{3}\right)_{2}$ which prevent the reaction between $\mathrm{Ca}^{2+}$ and $\mathrm{P}$ (phosphate), organic anions compete with phosphorus ions on adsorption sites. (Turner et al., 2005) and added organic acids coat the particles of $\mathrm{CaCO}_{3}$ preventing the reaction between $\mathrm{CaCO}_{3}$ and $\mathrm{P}$ which caused $\mathrm{P}$ precipitation and fixation in insoluble forms as dicalcium phosphate dehydrate (DCP; $\left.\mathrm{CaHPO}_{4} .2 \mathrm{H}_{2} \mathrm{O}\right)$ or octacalcium phosphate [OCP; $\left.\mathrm{Ca}_{8} \mathrm{H}_{2}\left(\mathrm{PO}_{4}\right)_{6} \cdot 5 \mathrm{H}_{2} \mathrm{O}\right]$.

Also, humic acid can affect the solubility of insoluble phosphorus compounds in calcareous soil by its chelation capacity Similar results on calcareous soils were obtained by Tan, (2003) and Wandruszka, (2006).

The relative effects of the studied treatments of organic acids on $P$ availability may be cleared by the calculated values of $R C(\%)$ of available $P$, when these values were positive where the higher values of RC of available $\mathrm{P}$ were recorded with the treatments of $0.4 \% \mathrm{OA}$. The presented data in Tables (9) showed that, the calcareous soils content $(\mathrm{mg} / \mathrm{kg})$ of available phosphorus was increased with increasing salinity level of irrigation water. These increases due to the compete influences of soluble anions in irrigation water with phosphate anions for adsorption on the soil surface. This is in agreement with the results obtained by Kabba and Aulakh (2004).

Regarding to the calculated values of RC (\%) of soil content of available phosphorus (A-P) which recorded in Table (9), it can be noticed that, under different salinity level treatments of irrigation water, all values of RC A-P were positive and it increased positively with increasing salinity level and SAR values of water resources. This trend was found in the two calcareous soils at different application rates of the used organic acids. In this respect, Wenju et al. (2008); Abou Hussien et al. (2010) and Hamad (2009) obtained similar results. This positive effect of sodium hazard (SAR or $\mathrm{Na}^{+}$concentration) of irrigation water on the content $(\mathrm{mg} / \mathrm{kg})$ of available phosphorus could be explained by effect of sodium ions on soil $\mathrm{P}$ solubility. These results are in agreement with those obtained by Abou Hussien et al. (2009) and Fayed (2009). All values of RC (\%) of available $P$ as affected by salinity levels of irrigation water were positive, where the high values were found in the soil irrigated with W3 (Table, 9). 
Tantawy, Manal F. et al. 


\section{REFERENCES}

Abd El-Kader, G. A., 2006. Physical, chemical and mineralogical studied on some calcareous soils of Egypt. Ph.D. Thesis Fac. of Agri. Benha Univ. Egypt.

Abou Hussien, E. A., S. W. Barsoum, B. Y. El-Koumey and S. A. S. Fayed 2009. Sandy soil properties and its productivity as affected by irrigation water quality. Minoufiya J. Agric., Res., 34 (5) 1945-1958.

Abou Hussien, E. A., B. Y. El-Koumey, F. S. El-Shafiey and H. M. A. Gohar 2012. Effect of composted plant residues on newly reclaimed soils properties and its productivily. Minoufiya J. Agri. Res. 37 (1) 231-245.

Abou Hussien, E. A., S. A. Radwan, R. A. Khalil and M. M. Hamad 2010. Phosphorus forms in calcareous soils as affected by irrigation water salinity. International Soil Sci. Congress on "Management of Natural Resources to Sustain Soil Health and Quality" Ondokuz Mayis Univ., Samsun, Turkey, 26 - 28 may, 2010, $175-183$.

Al-Busaidi, A. S. and P. Cookson 2003. Salinity-pH relationships in calcareous soil. Agricultural and Marine Sci., 8 (1) 41 - 46.

A. O. A. C., Association of Official Analytical Chemists 2000 .Official Methods of Agriculture Chemists. $17^{\text {th }}$ Ed. Pub. A.O.A.C., Washington, D. C., U.S.A.

Beheiry, G. S. and A. A. Soliman 2005. Wheat productivity in previously organic treated calcareous soil irrigated with saline water. Egypt. J. Appl. Sci. 20:363-376.

Boroojeni, A. K., F. Noorbakhsh, M. Afyuni and H. Shariatmadari 2007. Different forms of lead, nickel and cadmium in a calcareous soil treated with sewage sludge. J. of Sci. and Technology of Agriculture and Natural Resources, 11(1) 41-53.

Caravaca, F., Lax, A. and J. Albaladejo 1999. Organic matter, nutrient contents and cation exchange capacity in fine fractions from semiarid calcareous soils. Geoderma, 93:161-176

Cottenie, A., M. Verloo, L. Kikens, G. Velghe and R. Camerlynck 1982. Analytical Problems and Methods in Chemical Plant and Soil Analysis. Hand book Ed. A. Cottenie, Gent, Belgium.

DelCampillo, M. C., J. Torrent and R. H. Looppert 1992. The reactivity of carbonates in selected soils of southern Spain. Geoderma., 52 : 149160.

El-Fishy, M. A. A., 2009. Effect of different sources of organic fertilizers and irrigation water on availability of some nutrients in soils. Ph. D. Thesis, Fac. of Agri. Minoufiya Univ., Egypt.

El-Maghraby, T. A and S. M. Shaban 2011. Ameliorating calcareous soil properties and agriculture methods for achieving the sustainable agriculture aspect. J. Soil Sci. and Agric. Eng., Mansoura Univ., 2 (5) $541-554$. 
Emam, A. A. E., 2011. Effect of irrigation water salinity on organic matter in soil and status of some nutrients. M. Sc. Thesis, Fac. of Agric. Minoufiya Univ., Egypt.

FAO., 2002. Agriculture drainage water management in arid and semi-arid areas. Irrigation and drainage pp 61, Rome

Fayed, S. A. S., 2009. Effect of irrigation with sewage and drainage water on properties of some new reclaimed soils and plants growth. M.Sc. Thesis, Fac. of Agric. Minoufiya. Univ., Egypt.

Gohar, H. M. A., 2011. Effect of some plant residues on soil properties and plant growth in newly reclaimed soils. M. Sc. Thesis, Fac. of Agric. Minoufiya Univ., Egypt.

Hamad, M. M. H., 2009. Effect of saline irrigation water on calcareous soil properties and its productivity. Ph. D. Thesis, Fac. of Agri. Minoufiya Univ., Egypt.

Hassan, M. A., 2009. Effect of organic and chemical amendments on soil properties and yield production. Ph.D. Thesis, Fac. of Agri. Minoufiya Univ., Egypt.

Ismail, A. S., A. S. El-Sebaay, S. A. Saleh and A. F. Abdel-Wahab 1996. Effect of application of mineral and organic amendments on nodulation, cowpea growth and certain chemical properties of calcareous soils. Proceedings of the Sixth Conference of Agricultural Development Res., 17-19 December..

Kabba, B. S. and M. S. Aulakh 2004. Climatic conditions and crop residue quality differentially affect $\mathrm{N}, \mathrm{P}$, and $\mathrm{S}$ mineralization in soils with contrasting P status. J. Plant Nutr. Soil Sci. 167:596-601.

Kim, H. T., 1996. Soil Sampling, Preparation and Analysis, Marcal Dekker, Inc. New York, pp 391.

Kononova, M. M., 1966. Soil Organic Matter. Pergamon, Oxford, pp. 190-199.

Leal, R. M., U. W. E. Herpin, A.F. Da Fonseca, L.P. Firme, C. R. Montes and A.J. Melfi 2009. Sodicity and salinity in a Brazilian Oxisol cultivated with sugarcane irrigated with wastewater. Agricultural Water Management. 96 (2) 307-316.

Levy, G. J., A. I. Mamedov and D. Goldstein 2003. Sodicity and water quality effects on slaking of aggregates from semi- arid soils. Soil Science 168(8) 552- 562.

Mohamed, A. I., O. M. Ali and M. A. Matloub 2007. Effect of soil amendments on some physical and chemical properties of some soils of Egypt under saline irrigation water. African Crop Science Conference Proceedings, 8: 1571-1578.

Mojiri, A., A. Jalalian and H. Radnezhad 2011. Effects of urban wastewater treatments on chemical properties of saline and calcareous soil. J. of Applied Sci. Research., 7(3) 222-228.

Moreno, F., J. M. Murillo, F. Pelegrin and I. F. Giran 2006. Long-term impact of conservation tillage on stratification ratio of soil organic carbon and loss of total and active $\mathrm{CaCO}_{3}$ soil. Soil and Tillage Research, 85: 8693. 
Moursy, M. E., 2002. Assessment of some methods for improving the fertility of calcareous soils in Nubaria North Tahreer, Egypt, Ph.D. Thesis Fac. of Agri. Moshtohor Zagazig, Univ., Benha Branch, Egypt

Page, A. L., R. H. Miller and D. R. Keeney 1982. Methods of Soil Analysis. Part2: Chemical and microbiological properties (2nd ed) Amer. Soc. Agron. In Soil Sci. Soc. Am. Inc Madison, WI.

Panahpour, E., E. Pazira, P. Najafi, A. Moezzi and K. Ordookhani 2011. The effect of compost leachate on $\mathrm{pH}, \mathrm{EC}$ and soil organic matter in the Gavart region of Isfahan. Advances in Environmental Biology, 5(4) 624630.

Prieto-Méndez, J., H. Rubio-Arias and F. Prieto-García 2011. Soil quality in terms of pyhsical- hemical-metal properties for barely (Hordeum vulgare) production in the State of Hidalgo, Mexico. American-Eurasian J. Agric. \& Environ. Sci., 10 (2) 230-237.

Ragab, A. A. M., F. A. Hellal and M. Abd El-Hady 2008. Irrigation water salinity effects on some soil water constant and plant. Twelfth International Water Technology Conference, IWTC12 2008, Alexandria, Egypt, pp. $625-638$.

Reyhanitabar, A. and R. J. Gilkes 2010. The reactivity of carbonates in selected soils from Iran. World Congress of Soil Science, Soil Solutions for a Changing World. 19:37-39.

Sarwar, G., H. Schmeisky, N. Hussain, S. Muhammadi, M. Ibrahim and E. Safdar 2008. Improvement of soil physical and chemical properties with compost application in rice-wheat cropping system. Pak. J. Bot., 40(1) 275-282.

Schnitzer, M. and S. U. Khan 1978. Soil Organic Matter. Elsevier Scientific Publishing Amsterdam, Oxford, New York.

Tan, K. H., 2003. Humic Matter in Soil and Environment, Principles and Controversies. New York, USA, pp $154-278$.

Turner, B. L., E. Frossard and D. S. Baldwin 2005. Organic phosphorus in the environment. Cambridge, MA, CABI, Publishing. pp. 366 - 369.

Wandruszka, R.V., 2006. Phosphorus retention in calcareous soils and the effect of organic matter on its mobility. Geochemical Transactions, 7(6) $1-8$.

Wenju, M., Z. Yu and Z. Mao 2008. Effects of saline irrigation water on soil salinity and yield of winter wheat-maize in North China Plain. Irrigation Drainage Syst, 22: 3 - 18. 
Tantawy, Manal F. et al.

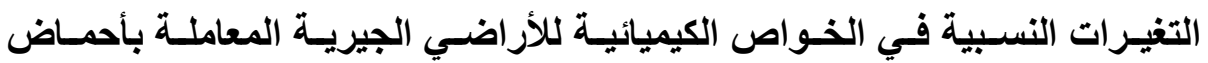

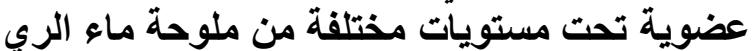

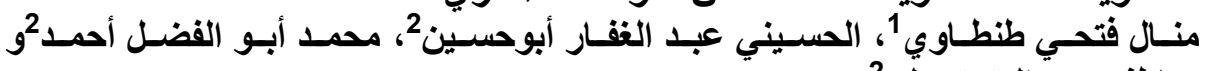
عاطف عبد العزيز علّي 2

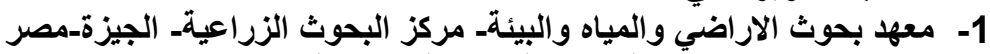

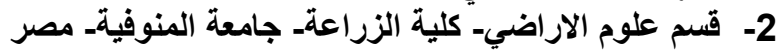

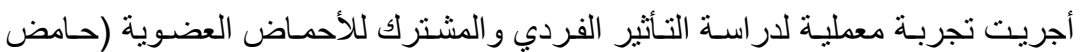

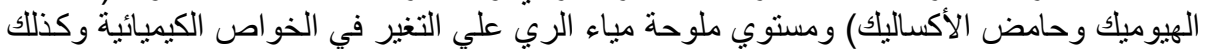

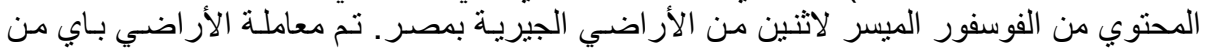

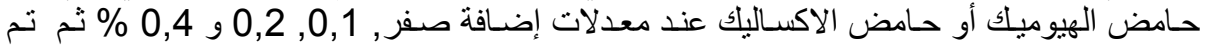

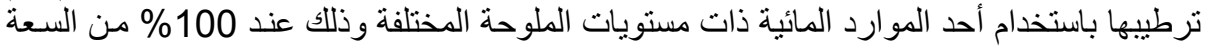

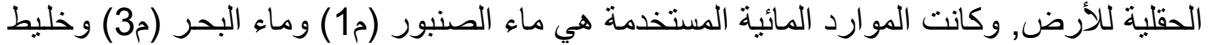

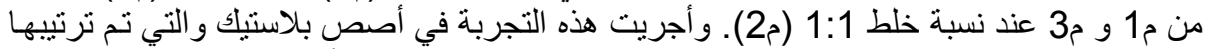

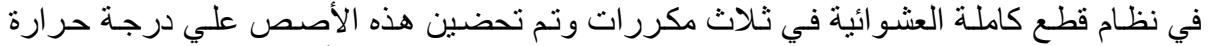

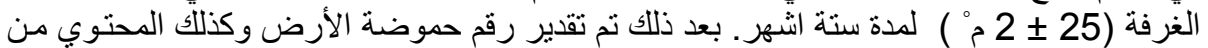

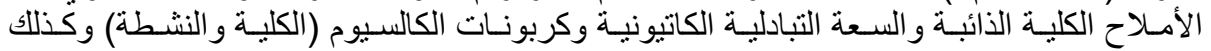

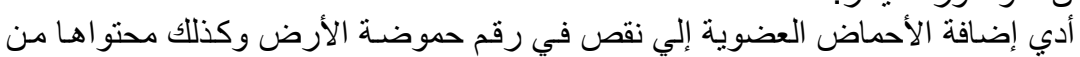
المحتوي من الفوسفور الميسر.

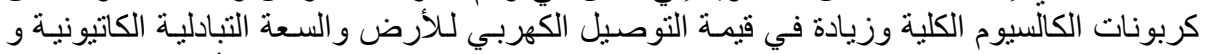

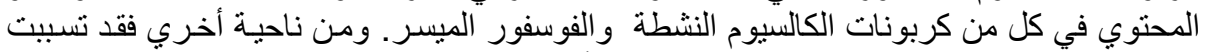

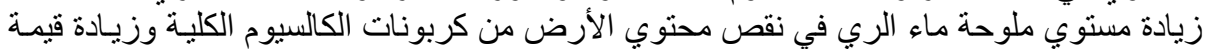

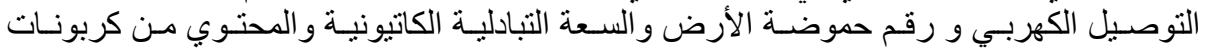

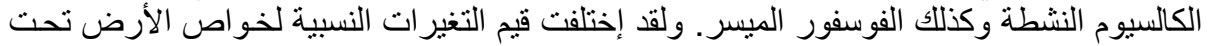

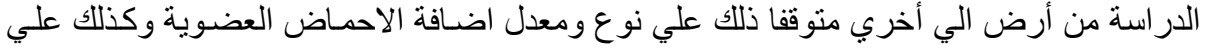

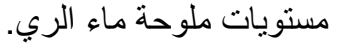

كلية الزراعة - جامعة المنصورة قام بتحكيم البحث مركز البحوث الزراعية

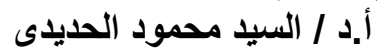
أ.د / نبيل سبع الرجال عبد الحميد 
J. Soil Sci. and Agric. Eng., Mansoura Univ., Vol. 3 (10), October, 2012 
J.Soil Sci. and Agric. Eng., Mansoura Univ., Vol. 3 (10): 1017 - 1032, 2012

Table (5): Effect of the studied treatments on calcareous soil EC $\left(\mathrm{dSm}^{-1}\right)$ and its relative change (RC \%)

\begin{tabular}{|c|c|c|c|c|c|c|c|c|c|c|c|c|c|c|c|}
\hline \multirow{3}{*}{$\begin{array}{l}\text { ż } \\
\dot{\bar{c}}\end{array}$} & \multirow{3}{*}{ 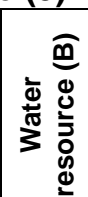 } & \multirow{2}{*}{\multicolumn{2}{|c|}{ Control }} & \multicolumn{6}{|c|}{ Humic acid $(A)$} & \multicolumn{6}{|c|}{ Oxalic acid (A) } \\
\hline & & & & \multicolumn{2}{|c|}{0.10} & \multicolumn{2}{|c|}{0.20} & \multicolumn{2}{|c|}{0.40} & \multicolumn{2}{|c|}{0.10} & \multicolumn{2}{|c|}{0.20} & \multicolumn{2}{|c|}{0.40} \\
\hline & & $\mathrm{dSm}^{-1}$ & RC \% & $\mathrm{dSm}^{-1}$ & RC \% & $\mathrm{dSm}^{-1}$ & RC \% & $\mathrm{dSm}^{-1}$ & RC \% & $\mathrm{dSm}^{-1}$ & RC \% & $d \mathrm{dSm}^{-1}$ & RC \% & $\mathrm{dSm}^{-1}$ & RC \% \\
\hline \multirow{3}{*}{1} & W1 & 4.2 & 1.9 & 4.4 & 7.3 & 4.4 & 7.8 & 4.9 & 18.4 & 4.4 & 5.6 & 4.8 & 15.3 & 4.9 & 18.0 \\
\hline & W2 & 12.6 & 205.8 & 13.3 & 222.8 & 14.2 & 244.7 & 14.4 & 249.5 & 14.0 & 239.8 & 14.2 & 244.7 & 14.6 & 254.4 \\
\hline & W3 & 32.8 & 696.1 & 33.2 & 705.8 & 34.0 & 725.2 & 34.7 & 742.2 & 32.5 & 688.8 & 33.3 & 708.3 & 33.5 & 713.1 \\
\hline \multicolumn{4}{|c|}{ L.S.D at 0.05} & \multicolumn{2}{|c|}{$A=0.71$} & $\mathrm{~B}=0.61$ & & & & & $A=0.82$ & & $\mathrm{~B}=0.71$ & & \\
\hline & W1 & 2.2 & 141.3 & 2.5 & 166.3 & 3.5 & 278.3 & 3.6 & 285.9 & 1.4 & 56.5 & 1.5 & 60.9 & 1.5 & 63.0 \\
\hline \multirow[t]{2}{*}{2} & W2 & 13.2 & 1334.8 & 15.0 & 1530.4 & 16.4 & 1682.6 & 16.5 & 1693.5 & 14.0 & 1421.7 & 16.1 & 1650.0 & 17.0 & 1747.8 \\
\hline & W3 & 18.1 & 1867.4 & 19.3 & 1997.8 & 19.5 & 2019.6 & 20.5 & 2128.3 & 18.6 & 1921.7 & 20.1 & 2084.8 & 21.2 & 2204.3 \\
\hline \multicolumn{4}{|c|}{ L.S.D at 0.05} & $A=0.62$ & & $\mathrm{~B}=0.53$ & & & & & $A=0.44$ & & $\mathrm{~B}=0.38$ & & \\
\hline
\end{tabular}

Table (6): Effect of the studied treatments on the cation exchange capacity (CEC) as meq/100g soil of calcareous soils and its relative change $(\mathrm{RC} \%)$

\begin{tabular}{|c|c|c|c|c|c|c|c|c|c|c|c|c|c|c|c|}
\hline \multirow{3}{*}{$\begin{array}{l}\text { Soil } \\
\text { No. }\end{array}$} & \multirow{3}{*}{$\begin{array}{c}\text { Water } \\
\text { resource } \\
\text { (B) }\end{array}$} & \multirow{2}{*}{\multicolumn{2}{|c|}{ Control }} & \multicolumn{6}{|c|}{ Humic acid $(A)$} & \multicolumn{6}{|c|}{ Oxalic acid $(A)$} \\
\hline & & & & \multicolumn{2}{|c|}{0.10} & \multicolumn{2}{|c|}{0.20} & \multicolumn{2}{|c|}{0.40} & \multicolumn{2}{|c|}{0.10} & \multicolumn{2}{|c|}{0.20} & \multicolumn{2}{|c|}{0.40} \\
\hline & & $\begin{array}{l}\mathrm{meq} / \\
100 \mathrm{~g}\end{array}$ & $\begin{array}{c}\text { RC } \\
\%\end{array}$ & $\begin{array}{l}\mathrm{meq} / \\
100 \mathrm{~g}\end{array}$ & $\begin{array}{c}\mathbf{R C} \\
\%\end{array}$ & $\begin{array}{l}\mathrm{meq} / \\
100 \mathrm{~g}\end{array}$ & RC \% & $\begin{array}{l}\text { meq/ } \\
100 \mathrm{~g}\end{array}$ & $\begin{array}{c}\mathbf{R C} \\
\%\end{array}$ & $\begin{array}{l}\mathrm{meq} / \\
100 \mathrm{~g}\end{array}$ & $\begin{array}{c}\mathbf{R C} \\
\%\end{array}$ & $\begin{array}{l}\text { meq/ } \\
100 \mathrm{~g}\end{array}$ & $\begin{array}{c}\mathbf{R C} \\
\%\end{array}$ & $\begin{array}{l}\text { meq/ } \\
100 \mathrm{~g}\end{array}$ & $\begin{array}{c}\mathbf{R C} \\
\%\end{array}$ \\
\hline \multirow{3}{*}{1} & W1 & 19.7 & 13.3 & 21.0 & 20.8 & 22.3 & 28.2 & 23.7 & 36.3 & 20.0 & 15.0 & 21.0 & 20.8 & 22.6 & 30.0 \\
\hline & W2 & 19.5 & 12.1 & 21.5 & 23.6 & 22.4 & 28.8 & 24.3 & 39.7 & 21.0 & 20.8 & 21.6 & 24.2 & 23.0 & 32.3 \\
\hline & W3 & 20.8 & 19.6 & 22.1 & 27.1 & 23.9 & 37.4 & 26.1 & 50.1 & 20.1 & 15.6 & 22.2 & 27.7 & 23.2 & 33.4 \\
\hline \multicolumn{2}{|c|}{ L.S.D at 0.05} & & & $A=0.55$ & & $\mathrm{~B}=0.48$ & & & & & $A=0.61$ & & $\mathrm{~B}=0.53$ & & \\
\hline \multirow{3}{*}{2} & W1 & 19.0 & 15.2 & 19.7 & 19.4 & 20.4 & 23.6 & 22.0 & 33.3 & 18.4 & 11.5 & 19.5 & 18.2 & 21.7 & 31.5 \\
\hline & W2 & 19.6 & 18.8 & 20.0 & 21.2 & 22.6 & 37.0 & 23.2 & 40.6 & 19.1 & 15.8 & 20.3 & 23.0 & 21.8 & 32.1 \\
\hline & W3 & 20.0 & 21.2 & 20.7 & 25.5 & 22.9 & 38.8 & 24.2 & 46.7 & 19.5 & 18.2 & 21.0 & 27.3 & 22.6 & 37.0 \\
\hline \multicolumn{2}{|c|}{ L.S.D at 0.05} & & & $A=0.65$ & & $\mathrm{~B}=0.56$ & & & & & $A=0.63$ & & $\mathrm{~B}=0.52$ & & \\
\hline
\end{tabular}


Table (7): Effect of the studied treatments on calcareous soil content (\%) of total calcium carbonate $\left(\mathrm{T}-\mathrm{CaCO}_{3}\right)$ and its relative change ( $\mathrm{RC} \%)$

\begin{tabular}{|c|c|c|c|c|c|c|c|c|c|c|c|c|c|c|c|}
\hline \multirow{3}{*}{$\begin{array}{l}\text { Soil } \\
\text { No. }\end{array}$} & \multirow{3}{*}{ 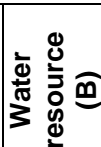 } & \multirow{2}{*}{\multicolumn{2}{|c|}{ Control }} & \multicolumn{6}{|c|}{ Humic acid (A) } & \multicolumn{6}{|c|}{ Oxalic acid (A) } \\
\hline & & & & \multicolumn{2}{|c|}{0.10} & \multicolumn{2}{|c|}{0.20} & \multicolumn{2}{|c|}{0.40} & \multicolumn{2}{|c|}{0.10} & \multicolumn{2}{|c|}{0.20} & \multicolumn{2}{|c|}{0.40} \\
\hline & & $\%$ & RC \% & $\%$ & $\mathbf{R C} \%$ & $\%$ & $\mathbf{R C} \%$ & $\%$ & RC \% & $\%$ & RC \% & $\%$ & RC \% & $\%$ & RC \% \\
\hline \multirow{3}{*}{1} & W1 & 24.3 & -16.8 & 23.0 & -21.2 & 22.5 & -22.9 & 22.3 & -23.6 & 23.2 & -20.5 & 20.7 & -29.1 & 19.4 & -33.6 \\
\hline & W2 & 22.0 & -24.7 & 21.2 & -27.4 & 20.5 & -29.8 & 18.0 & -38.4 & 20.0 & -31.5 & 20.4 & -30.1 & 19.2 & -34.2 \\
\hline & W3 & 20.7 & -29.1 & 19.1 & -34.6 & 18.6 & -36.3 & 18.1 & -38.0 & 19.7 & -32.5 & 20.2 & -30.8 & 18.2 & -37.7 \\
\hline \multicolumn{2}{|c|}{ L.S.D at 0.05} & & & \multicolumn{2}{|c|}{$A=0.55$} & \multicolumn{4}{|c|}{$\mathrm{B}=0.48$} & & \multicolumn{2}{|c|}{$A=0.53$} & \multicolumn{3}{|c|}{$B=0.46$} \\
\hline \multirow{3}{*}{2} & W1 & 35.8 & -14.4 & 35.3 & -15.6 & 34.3 & $\begin{array}{l}-17.9 \\
\end{array}$ & 33.6 & -19.6 & 36.3 & -13.2 & 36.8 & -12.0 & 35.8 & -14.4 \\
\hline & W2 & 33.7 & -19.4 & 33.1 & -20.8 & 33.2 & -20.6 & 32.6 & -22.0 & 34.4 & -17.7 & 34.1 & -18.4 & 33.4 & -20.1 \\
\hline & W3 & 31.7 & -24.2 & 31.4 & -24.9 & 30.6 & -26.8 & 30.2 & -27.8 & 33.1 & -20.8 & 32.9 & -21.3 & 31.9 & -23.7 \\
\hline \multicolumn{2}{|c|}{ L.S.D at 0.05} & & & \multicolumn{2}{|c|}{$A=0.45$} & \multicolumn{4}{|c|}{$\mathrm{B}=0.39$} & & \multicolumn{2}{|c|}{$A=0.41$} & \multicolumn{3}{|c|}{$\mathrm{B}=0.35$} \\
\hline
\end{tabular}

Table (8): Effect of the studied treatments on calcareous soil content (\%) of active calcium carbonate $\left(\mathrm{A}-\mathrm{CaCO}_{3}\right)$ and its relative change ( $\mathrm{RC} \%)$

\begin{tabular}{|c|c|c|c|c|c|c|c|c|c|c|c|c|c|c|c|}
\hline \multirow{3}{*}{$\frac{\dot{2}}{\text { க் }}$} & \multirow{3}{*}{ 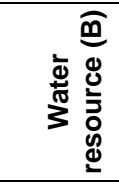 } & \multirow{2}{*}{\multicolumn{2}{|c|}{ Control }} & \multicolumn{6}{|c|}{ Humic acid (A) } & \multicolumn{6}{|c|}{ Oxalic acid (A) } \\
\hline & & & & \multicolumn{2}{|c|}{0.10} & \multicolumn{2}{|c|}{0.20} & \multicolumn{2}{|c|}{0.40} & \multicolumn{2}{|c|}{0.10} & \multicolumn{2}{|c|}{0.20} & \multicolumn{2}{|c|}{0.40} \\
\hline & & $\%$ & RC \% & $\%$ & $\mathbf{R C} \%$ & $\%$ & RC $\%$ & $\%$ & RC \% & $\%$ & RC \% & $\%$ & RC \% & $\%$ & RC $\%$ \\
\hline \multirow{3}{*}{1} & W1 & 11.6 & 20.8 & 11.8 & 22.9 & 11.9 & 24.0 & 11.9 & 24.0 & 11.3 & $\begin{array}{ll}17.7 \\
\end{array}$ & 11.3 & $\begin{array}{ll}17.7 \\
\end{array}$ & 11.5 & 19.8 \\
\hline & $\mathrm{W} 2$ & 10.2 & 6.3 & 10.7 & 11.5 & 10.9 & 13.5 & 11.2 & 16.7 & 10.7 & 11.5 & 10.7 & 11.5 & 10.9 & 13.5 \\
\hline & W3 & 10.4 & 8.3 & 10.5 & 9.4 & 10.7 & 11.5 & 10.9 & 13.5 & 10.1 & 5.2 & 10.4 & 8.3 & 10.7 & 11.5 \\
\hline \multicolumn{2}{|c|}{ L.S.D at 0.05} & & & \multicolumn{2}{|c|}{$\mathrm{A}=0.31$} & \multicolumn{4}{|c|}{$\mathrm{B}=0.27$} & & \multicolumn{2}{|c|}{$A=0.37$} & \multicolumn{3}{|c|}{$\mathrm{B}=0.32$} \\
\hline \multirow{3}{*}{2} & W1 & 11.0 & 1.9 & 12.5 & 15.7 & 12.9 & 19.4 & 13.1 & 21.3 & 11.2 & 3.7 & 11.6 & 7.4 & 12.3 & 13.9 \\
\hline & W2 & 10.5 & -2.8 & 11.5 & 6.5 & 11.5 & 6.5 & 11.9 & 10.2 & 10.4 & -3.7 & 10.9 & 0.9 & 11.0 & 1.9 \\
\hline & W3 & 10.5 & -2.8 & 10.9 & 0.9 & 11.0 & 1.9 & 11.7 & 8.3 & 10.6 & -1.9 & 10.7 & -0.9 & 10.9 & 0.9 \\
\hline \multicolumn{2}{|c|}{ L.S.D at 0.05} & & & \multicolumn{2}{|c|}{$\mathrm{A}=0.43$} & \multicolumn{4}{|c|}{$\mathrm{B}=0.38$} & & \multicolumn{2}{|c|}{$A=0.49$} & \multicolumn{3}{|c|}{$\mathrm{B}=0.42$} \\
\hline
\end{tabular}


Tantawy, Manal F. et al.

Table (9): Effect of the studied treatments on calcareous soil content ( $\mathrm{mg} / \mathrm{kg}$ soil) of available phosphorous and its relative change ( $\mathrm{RC} \%)$

\begin{tabular}{|c|c|c|c|c|c|c|c|c|c|c|c|c|c|c|c|}
\hline \multirow{3}{*}{$\frac{\text { o }}{\text { zo }}$} & \multirow{3}{*}{ 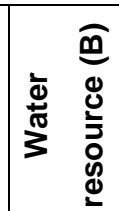 } & \multirow{2}{*}{\multicolumn{2}{|c|}{ Control }} & \multicolumn{6}{|c|}{ Humic acid (A) } & \multicolumn{6}{|c|}{ Oxalic acid (A) } \\
\hline & & & & \multicolumn{2}{|c|}{0.10} & \multicolumn{2}{|c|}{0.20} & \multicolumn{2}{|c|}{0.40} & \multicolumn{2}{|c|}{0.10} & \multicolumn{2}{|c|}{0.20} & \multicolumn{2}{|c|}{0.40} \\
\hline & & $\begin{array}{c}\mathbf{m g} / \mathbf{k g} \\
\text { soil }\end{array}$ & RC \% & $\begin{array}{c}\mathbf{m g} / \mathbf{k g} \\
\text { soil }\end{array}$ & $\mathrm{RC} \%$ & $\begin{array}{c}\mathrm{mg} / \mathrm{kg} \\
\text { soil }\end{array}$ & RC \% & $\begin{array}{c}\mathrm{mg} / \mathbf{k g} \\
\text { soil }\end{array}$ & $\mathrm{RC} \%$ & $\begin{array}{c}\mathrm{mg} / \mathbf{k g} \\
\text { soil }\end{array}$ & RC \% & $\begin{array}{c}\mathrm{mg} / \mathbf{k g} \\
\text { soil }\end{array}$ & $\mathbf{R C} \%$ & $\begin{array}{c}\mathbf{m g} / \mathbf{k g} \\
\text { soil }\end{array}$ & RC \% \\
\hline \multirow{3}{*}{1} & W1 & 3.7 & -59.8 & 3.7 & -59.8 & 4.0 & -56.5 & 4.1 & -55.4 & 6.7 & -27.2 & 6.9 & -25.0 & 7.1 & -22.8 \\
\hline & W2 & 5.1 & -44.6 & 5.3 & -42.4 & 5.3 & -42.4 & 5.4 & -41.3 & 8.0 & -13.0 & 8.2 & -10.9 & 8.5 & -7.6 \\
\hline & W3 & 7.4 & -19.6 & 7.5 & -18.5 & 7.8 & -15.2 & 8.0 & -13.0 & 8.5 & -7.6 & 8.5 & -7.6 & 8.8 & -4.3 \\
\hline \multicolumn{2}{|c|}{ L.S.D at 0.05} & & & \multicolumn{2}{|c|}{$A=0.29$} & \multicolumn{4}{|c|}{$\mathrm{B}=0.26$} & & \multicolumn{2}{|c|}{$A=0.40$} & \multicolumn{3}{|c|}{$B=0.35$} \\
\hline \multirow{3}{*}{2} & W1 & 9.0 & 15.4 & 9.3 & 19.2 & 9.4 & 20.5 & 9.7 & 24.4 & 8.5 & 9.0 & 8.6 & 10.3 & 8.9 & 14.1 \\
\hline & W2 & 9.1 & 16.7 & 9.1 & 16.7 & 9.2 & 17.9 & 9.3 & 19.2 & 9.7 & 24.4 & 10.0 & 28.2 & 10.2 & 30.8 \\
\hline & W3 & 11.5 & 47.4 & 12.0 & 53.8 & 12.7 & 62.8 & 13.0 & 66.7 & 12.4 & 59.0 & 12.6 & 61.5 & 12.6 & 61.5 \\
\hline \multicolumn{2}{|c|}{ L.S.D at 0.05} & & & \multicolumn{2}{|c|}{$A=0.46$} & \multicolumn{4}{|c|}{$B=0.40$} & & \multicolumn{2}{|c|}{$A=0.48$} & \multicolumn{3}{|c|}{$B=0.41$} \\
\hline
\end{tabular}

